\title{
Authentic Assessment in English Textbook "Stop Bullying Now" Used for the Eleventh Grade Students of Senior High School
}

\author{
${ }^{1}$ Ridwan*, ${ }^{2}$ Sri Wahyuningsih, ${ }^{3}$ Winarno \\ Universitas Borneo Tarakan \\ *Corresponding Author \\ Email: ridwan.fkipubt@gmail.com
}

\begin{abstract}
The objectives of the present research were to describe the characteristics of authentic assessment used in the English Textbook "Stop Bullying Now" and to find out the characteristics of the most dominant authentic assessment applied in the book "Stop Bullying Now" used for the eleventh grade students of senior high school. This research was a library research using a qualitative descriptive approach. The data which were obtained from document analysis were analyzed using concurrent activity flows from (Miles et al, 2014). The results of this research showed that the textbook had applied authentic assessments to all English skills: listening, speaking, reading, and writing. However, among the four skills, listening was the skill with the least activity. The textbook applied eight out of nine characteristics (realistic activity or context, cognitively complex, performance-based, formative assessment, collaborative, defense is required, multiple indicators or portfolio, and mastery expectation). The textbook did not apply the criteria known by students because it did not illustrate how teacher assessed students' work. The most dominant criteria used in this textbook was realistic activity or context. This textbook also took a lot of materials related to the real-life of students.
\end{abstract}

Keywords: textbook analysis, English textbook, authentic assessment

\section{INTRODUCTION}

Textbooks are one of the resources materials in the process of learning that are often used by teachers and students in schools. As a main resource, textbooks must enhance the quality of educational process. Textbooks are not only useful for teachers to set up the material and attain teaching goals and objectives, but as well to help to achieve the learning needs of students. The effectiveness of textbooks in formulating aims and objectives, as well as the preparation of educational materials, is a great consideration before decision is made to use the textbook in classroom. This reason makes the selection of textbooks used by the teachers relatively crucial. Textbooks must conform to the present curriculum, school syllabus, and student's needs as well as the aims and objectives of teaching. Thus, textbooks could also be boring for students if the content of material and tasks are presented in the same pattern yet expectable. To solve these problems, curriculum designers provide alternative solution in textbook. Alternative solution is primarily referred to as "authentic". Authentic is described as anything that relates to the real-world (Frey et al., 2012). As the current assessment method used in the 2013 curriculum, authentic assessment has been established by the government. The evaluation system in the 2013 curriculum uses authentic assessment which aims to assess student readiness, the learning process, and learning outcomes.

An authentic assessment is a method of assessment where students are asked to carry out real-word activities (Mueller, 2005). It is used to express the value of 
information and skills that is substantially applied in student's real life. According to Mueller (in Sari et al., 2019), there are several reasons for using authentic assessment. First, authentic assessments are direct measures. Students will get to use the skills and knowledge that have learned in real world and will provide the most direct evidence. Second, an authentic assessment reflects the constructive nature of learning. Students can not only ask to repeat the information that have received, but also have to be asked to prove that the students have precisely constructed the meaning of what has been taught. Third, authentic assessment provides multiple avenues for demonstrating learning. Students can use a variety of ways to demonstrate the knowledge and skills that have been acquired.

Unfortunately, application of authentic assessment has encountered several obstacles. Several researchers reported the obstacles found in carrying out authentic assessments. Zaim (2013) identified a number of problems related to the implementation of authentic assessment, particularly at secondary school. The application of an authentic assessment in the educational process was not good enough. In addition, the teachers still needed an instruction book and training to carry out the authentic assessment in the educational process. Teachers faced some difficulties in determining the objectives of the assessment, taking the students fairness, and making the objectivity and reliability of the assessment of students' works. It took longer because the teacher had to assess as many aspects as authentically as possible.

English textbooks for high school students have been widely published by many publishers and one of them is English textbook "Stop Bullying Now" that released by Indonesian Ministry of Education and Culture. Textbooks must have main instrument for working on the student's need. But sometimes some of them are inappropriate with the student's need (Handayani, 2016). To cope this issue, the implementation of authentic material is important in textbook. Tomlinson (2012) mentions most of the textbook material that students follow must be authentic in order for students to be prepared for future usage of English in the real world or outside of the classroom and to be able to communicate in the target language.

Both authentic materials and authentic assessments are essential education instruments which cannot be parted from one another. It is obvious that authentic assessment is essential learning aspect applicable to the usage of authentic material and to the needs of students (Idham, F. I., Nadrun, 2015). Indeed, it is quite difficult to find English textbooks that fulfils all of the requirements of good material that fits the student's need.

Extensive researches have shown that there are certain textbooks that do not correspond to the needs of students. Anshar et al (2014) discovered that there are certain inappropriate Junior High School textbooks which still needs improvement in terms of how to design and develop learning activities and add appropriate assistance features for teachers. Next, Handayani (2016) founds that the textbook needs revisions in terms of language forms, such as there is no authentic which use real-life English language, no brief and simple illustration and grammar clarification, and no language reflects a variety of registers and accents.

Therefore, it is important to evaluate textbooks. This textbook analysis is expected to be used as a reference for teachers in selecting and assessing the textbooks used in the classroom. To assess the authenticity of an assessment in this textbook analysis, nine authenticity dimensions were used (Frey, 2013): 
1. The context of the assessment

a. Realistic activity or context

b.Cognitively complex

c. Performance based

2. The role of the student

a.Formative assessment

b.Collaborative

c. Defense is required

3. The scorings

a. Criteria known by student

b.Multiple indicators or portfolio

c. Mastery expectation

The first dimension is the Context of the Assessment which is divided into three sub-categories: realistic activity or context, cognitively complex, and performance based. Realistic Activity or Context means that outside of an artificial classroom setting, the role and assessment methods are equivalent to what would be needed or anticipated in the real world. Performance-based, skill or ability is evaluated through product performance or development. Cognitively Complex means successful execution of tasks requires critical thinking or high levels of understanding.

The second dimension is Role of Student. It is also divided into three subcategories: formative assessment, collaborative, and defense is required. Formative Assessment is the assessment which is intended to provide feedbacks to student to control student's learning and the scores do not affect grades. Collaborative is that the students are asked to work with one another or with the teachers during the task. Defense is required means that students maintain or defend the answer or performance and this might be a formal, oral defense in front of the students and adults or it might be a written defense as part of the assessment.

The last dimension is Scoring Procedures. It also divided into three subcategories: criteria known by student, multiple indicators or portfolio, and mastery expectation. Criteria Known by Student means that the rules of assessment are well understood by all of the students or participate in student creations and teachers may have used these criteria as a part of their teaching. Portfolio or Multiple Indicators means that score on the assessment is a combination of several scores that reflect the quality of several components or product portfolios and student works. Mastery Expectation means that the task and scoring are intended to provide input or feedback on whether the student has mastered ability or skills as opposed to comparing the student to other students.

\section{METHOD}

\section{Design}

The design of this research was characterized as a research literature or library research. It is a research in which a number of actions such as library data gathering methods, reading and taking notes, and processing research materials are carried out (Zed, 2014). The researchers studied the authentic assessment provided in English textbook "Stop Bullying Now". The researchers employed descriptive 
qualitative processes to describe the characteristic of authentic assessment in the textbook.

\section{Research Instrument}

Instrument of the research is a tool for the researchers in collecting the data, which utilized to collect, measure, and evaluate data from participants related to the research topic (Trigueros, 2017). The main instrument of this research was the researchers themselves. To help acquire necessary data in this research, the researcher used characteristic of authentic assessment adopted from Frey (2013) as a research instrument that used to analyze the assessment contained in textbook.

\section{Data Analysis}

The data of this research were analyzed using analysis of procedures based on Miles et al (2014) which were consisted of three concurrent activity flows: data reduction, data display, and conclusion drawing/verification.

\section{FINDINGS AND DISCUSSION}

\section{Findings}

There are 9 criteria of authentic assessment proposed by Frey which were used to identify the authentic assessment in the English textbook "Stop Bullying Now". They are: (1) realistic activity or context, (2) cognitively complex, (3) performance based, (4) formative assessment, (5) collaborative, (6) defense is required, (7) multiple indicators or portfolio, (8) criteria known by students, and (9) mastery expectation. This evaluation is used to make sure that every category of authenticity of an assessment fulfilled within this textbook.

The textbook was organized systematically based on the complexity of activities in every chapter. It was arranged from simple activity to complex one. The beginning of the unit until the end of the chapter used the same format. It is divided into seven sections.

The first one is pre-activity section. This section is an introductory activity. It can be in the form of reading activities, games, conversations, and others which are related to the material to be studied. The second section is building blocks. Building blocks provide explanations and information that enable students to become independent learners and build correct language skills. It contains an explanation of the linguistic concepts being learned in each chapter, as well as examples of application and use in daily communication including grammar, vocabulary, and pronunciation. The third section is Let's Practice. This section contains exercises that students can do to test their understanding of the language concepts they have learned in the Building Blocks section and improve students' language skills.

The fourth section is active conversation. The activities in this part allow students to actively express their thoughts and opinions in English in relation to the subjects being studied and the context in which they are being presented. This activity also gives a huge scope for students to build critical thinking abilities by allowing them to study and understand the opinions of others. The fifth section is writing connection. Writing is a very important language skill to develop. The activities in this section are to familiarize students with expressing their ideas in written form in accordance with the linguistic concepts being studied. Next section 
is 'Let's create \& contribute'. This activity is designed to let students practice applying what they have studied. They are taught to be environmentally conscious and to think critically in order to contribute to their environment, at the very least about their school environment. Teachers must allow them to be imaginative and to be creative. The exercises in this section also attempt to familiarize students with working in groups to develop a thought, as well as to foster strong interpersonal interactions among members of the class community. The last section is formative assessment. This section describes the types and techniques of evaluation that will be carried out in the process of learning and student learning outcomes.

This textbook also provides an enrichment section. At the end of the Student Book, there is a section entitled Enrichment. This section contains materials that can be used by teachers as material for carrying out literacy activities given for the literacy needs of each chapter. It describes alternative activities that can be done as enrichment for students in need. There were 4 sections in enrichment part: prereading activity, reading activity, post-reading activity, and personal journal writing.

Pre-reading activity section consists of two activities, namely the first is Personal Connection, which is an activity that makes students feel the connection of the lessons they learned with themselves and their lives. Personal Connections help give them a clear picture of what they learn. Second, Genre Connection, this section provides information to students about the type of text (genre) they have read: what is the genre of the text the students have read and the position of that text genre in literature? and who are the famous writers for this type of writing (genre)? This section builds a relationship between students and the text to be studied.

Reading activity section explains how the process of reading activities is carried out and how the techniques are, so that students can understand the reading easily.

Post-reading section begins with the discussion questions. It is expected that the whole class must participate in conveying their ideas and thoughts related to the text that has been studied. The teacher acts as a facilitator. As far as possible the teacher does not intervene unless necessary. The purpose of this activity is to foster critical thinking skills and the courage to express ideas. This activity can also monitor the extent of students' personal reactions and responses to the text being studied.

Personal journal writing section is a tool that students can use to write or reflect on something that is in their minds, record their observations to imagine or connect the information they have just received with what they already know. If students want, they can tell something they wrote in their journals to their friends, without the teacher having to do it.

Based on the document analysis, it was found that authentic assessments were applied in English textbook "Stop Bullying Now" for eleventh grade students of senior high school. The assessments presented in the textbook were reflected in tasks. Those tasks were presented into four different skills (listening task, speaking task, reading task, and writing task) in Table 1, Table 2, Table 3, and Table 4. 
Table 1. Authentic Assessment in Listening Skill

\begin{tabular}{|c|c|c|c|}
\hline Chapter & Listening Task & Page & $\begin{array}{c}\text { Authentic } \\
\text { Assessment }\end{array}$ \\
\hline VII. & Pre-Activity: & & Context of the \\
\hline Meaning & Students are asked to listen a popular & & Assessment: \\
\hline Through & song played by the teacher. The teacher & & - $\quad$ Realistic \\
\hline Music & $\begin{array}{l}\text { can then ask students to guess the song's } \\
\text { title, singer, or composer, and to say one } \\
\text { word or phrase which represents the } \\
\text { message of the song. }\end{array}$ & 87 & $\begin{array}{l}\text { activity or } \\
\text { context }\end{array}$ \\
\hline
\end{tabular}

The assessment on students' listening skill was only proposed in chapter 7 . Chapter 7 displayed proportion of listening skill because this chapter explained about "Meaning through Music". There was only 1 activity in this textbook and used "realistic activity or context" of authentic assessment. Songs seem able to attract the students to listen in order to determine the tone. The students get the feeling and meaning of the song after knowing the tone.

Table 2. Authentic Assessment in Speaking Skill

\begin{tabular}{|c|c|c|c|}
\hline Chapter & Speaking Task & Page & Authentic Assessment \\
\hline \multirow{2}{*}{$\begin{array}{l}\text { I. Offers \& } \\
\text { Suggestions }\end{array}$} & $\begin{array}{l}\text { Active Conversation: } \\
\text { Students in pairs are asked to solve the problem given in } \\
\text { Active Conversation and share the outcome of the } \\
\text { discussion by acting it out in front of the teacher and their } \\
\text { classmates }\end{array}$ & 14 & $\begin{array}{l}\text { Context of the Assessment } \\
\text { - Realistic activity or context } \\
\text { - Cognitively complex } \\
\text { - Performance based } \\
\text { Role of Student } \\
\text { - Collaborative } \\
\text { - Defense is required } \\
\text { Scoring Procedures } \\
\text { - Mastery expectation }\end{array}$ \\
\hline & $\begin{array}{l}\text { Let's Create/Contribute: } \\
\text { Students are asked to make pairs and then choose one of the } \\
\text { tasks given in the Let's Create/Contribute section: } \\
\text { - Make a poster and put ideas and suggestions on the } \\
\text { poster and share them with teacher and classmates. } \\
\text { - Make a poster and come up with offers and then present } \\
\text { it in class. } \\
\text { - Create a dialogue using suggestions and offers on any } \\
\text { topic and perform a dialogue that have been made in } \\
\text { front of the class. }\end{array}$ & 16 & $\begin{array}{l}\text { Context of the Assessment } \\
\text { - Realistic activity or context } \\
\text { - Cognitively complex } \\
\text { - Performance based } \\
\text { Role of Student } \\
\text { - Collaborative } \\
\text { Scoring Procedures } \\
\text { - Mastery expectation }\end{array}$ \\
\hline \multirow[b]{2}{*}{$\begin{array}{l}\text { II. Opinions } \\
\& \text { Thoughts }\end{array}$} & $\begin{array}{l}\text { Active Conversation: } \\
\text { Students are asked to complete the transactional } \\
\text { conversations and perform a role play to re-enact the } \\
\text { conversation with their classmates }\end{array}$ & 27 & $\begin{array}{l}\text { Context of the Assessment } \\
\text { - Realistic activity or context } \\
\text { - Cognitively complex } \\
\text { - Performance based } \\
\text { Role of Student } \\
\text { - Collaborative } \\
\text { Scoring Procedures } \\
\text { - Mastery expectation }\end{array}$ \\
\hline & $\begin{array}{l}\text { Let's Create/Contribute: } \\
\text { Students in pairs and groups are asked to choose one of the } \\
\text { many activities given in the Let's Create/Contribute section } \\
\text { of the book: } \\
\text { - Choose an issue and create questions to interview people } \\
\text { and write their opinions. After that, compile all the } \\
\text { opinions from interview results, then present the work in } \\
\text { the form of a role play, a poster, a movie or a PowerPoint } \\
\text { presentation. } \\
\text { - Write an opinion conversation using the expressions they } \\
\text { have learnt by using the role-play approach, re-enact the } \\
\text { opinion conversation they have made in front of the class. } \\
\text { - Find an editorial in any English newspaper or magazine } \\
\text { and use the visible thinking technique or "Reporter's } \\
\text { Notebook" to identify and separate facts and opinions }\end{array}$ & 30 & $\begin{array}{l}\text { Context of the Assessment } \\
\text { - Realistic activity or context } \\
\text { - Cognitively complex } \\
\text { - Performance based } \\
\text { Role of Student } \\
\text { - Collaborative } \\
\text { - Defense is required } \\
\text { Scoring Procedures } \\
\text { - Mastery expectation }\end{array}$ \\
\hline
\end{tabular}




\begin{tabular}{|c|c|c|c|}
\hline & $\begin{array}{l}\text { from that article and then express their opinion based on } \\
\text { the information they have at hand } \\
\text { - Debate with their classmate whether they agree or } \\
\text { disagree with motion "smoking should be banned in } \\
\text { public places" }\end{array}$ & & \\
\hline $\begin{array}{l}\text { III. Party } \\
\text { Time }\end{array}$ & $\begin{array}{l}\text { Active Conversation: } \\
\text { Students are asked to create a dialogue using expressions to } \\
\text { respond to invitations and perform a role play to re-enact } \\
\text { the conversation with their classmates }\end{array}$ & $40-41$ & $\begin{array}{l}\text { Context of the Assessment } \\
\text { - Realistic activity or context } \\
\text { - Cognitively complex } \\
\text { - Performance based } \\
\text { Role of Student } \\
\text { - Collaborative } \\
\text { Scoring Procedures } \\
\text { - Mastery expectation }\end{array}$ \\
\hline $\begin{array}{l}\text { IV. National } \\
\text { Disaster-An } \\
\text { Exposition }\end{array}$ & $\begin{array}{l}\text { Active Conversation: } \\
\text { Students are asked to create conversations based on the } \\
\text { prompts given and then discuss it with partner }\end{array}$ & 53 & $\begin{array}{l}\text { Context of the Assessment } \\
\text { - Realistic activity or context } \\
\text { - Cognitively complex } \\
\text { - Performance based } \\
\text { Role of Students } \\
\text { - Collaborative } \\
\text { - Defense is required } \\
\text { Scoring Procedures } \\
\text { - Mastery expectation }\end{array}$ \\
\hline $\begin{array}{l}\text { V. Letter } \\
\text { Writing }\end{array}$ & $\begin{array}{l}\text { Active Conversation: } \\
\text { Students are asked to create a dialogue and present the } \\
\text { dialogue that they have created by using role-play approach, } \\
\text { re-enact the conversation with their classmates }\end{array}$ & 70 & $\begin{array}{l}\text { Context of the Assessment } \\
\text { - Realistic activity or context } \\
\text { - Cognitively complex } \\
\text { - Performance based } \\
\text { Role of Student } \\
\text { - Collaborative } \\
\text { Scoring Procedures } \\
\text { - Mastery expectation }\end{array}$ \\
\hline \multirow{2}{*}{$\begin{array}{l}\text { VI. Cause } \\
\text { \& Effect }\end{array}$} & $\begin{array}{l}\text { Active Conversation: } \\
\text { Students are asked to create conversations with their } \\
\text { partners that should consist cause and effect expressions } \\
\text { and then present the conversation they have created using } \\
\text { role-play in front of the class }\end{array}$ & 82 & $\begin{array}{l}\text { Context of the Assessment } \\
\text { - Realistic activity or context } \\
\text { - Cognitively complex } \\
\text { - Performance based } \\
\text { Role of Student } \\
\text { - Collaborative } \\
\text { Scoring Procedures } \\
\text { - Mastery expectation }\end{array}$ \\
\hline & $\begin{array}{l}\text { Let's Create/Contribute: } \\
\text { Students in pairs are asked to choose one of the topics for } \\
\text { their project and then explore the consequences of the topic } \\
\text { by writing the cause and effect. After that, present the } \\
\text { project they have done using one of the following forms: } \\
\text { video, comic strip, PowerPoint presentation, or a blog }\end{array}$ & 84 & $\begin{array}{l}\text { Context of the Assessment } \\
\text { - Realistic activity or context } \\
\text { - Cognitively complex } \\
\text { - Performance based } \\
\text { Role of Student } \\
\text { - Collaborative } \\
\text { Scoring Procedures } \\
\text { - Mastery expectation }\end{array}$ \\
\hline $\begin{array}{l}\text { VII. } \\
\text { Meaning } \\
\text { Through } \\
\text { Music }\end{array}$ & $\begin{array}{l}\text { Active Conversation: } \\
\text { Students are asked to work in groups. each group arranges a } \\
\text { conversation about their favourite songs, poems, singers, } \\
\text { poets, and some questions as given in the textbook }\end{array}$ & 97 & $\begin{array}{l}\text { Context of the Assessment } \\
\text { - Realistic activity or context } \\
\text { - Performance based } \\
\text { Role of Student } \\
\text { - Collaborative } \\
\text { - Defense is required }\end{array}$ \\
\hline \multirow{2}{*}{$\begin{array}{l}\text { VIII. } \\
\text { Explain } \\
\text { This! }\end{array}$} & $\begin{array}{l}\text { Active Conversation: } \\
\text { Students are asked to choose one of the topics given and } \\
\text { research on it. After that, explain it to a friend or present it } \\
\text { in the class }\end{array}$ & 108 & $\begin{array}{l}\text { Context of the Assessment } \\
\text { - Realistic activity or context } \\
\text { - Cognitively complex } \\
\text { - Performance based } \\
\text { Scoring Procedures } \\
\text { - Mastery expectation }\end{array}$ \\
\hline & $\begin{array}{l}\text { Let's Create/Contribute: } \\
\text { Students are asked choose one of the activities that will be a } \\
\text { project they have to work on by creating a video, } \\
\text { PowerPoint presentation, poster or a pamphlet about the } \\
\text { formation of tsunamis or earthquakes }\end{array}$ & 112 & $\begin{array}{l}\text { Context of the Assessment } \\
\text { - Realistic activity or context } \\
\text { - Cognitively complex } \\
\text { - Performance based } \\
\text { Scoring Procedures } \\
\text { - Mastery expectation }\end{array}$ \\
\hline
\end{tabular}

Based on the table 2 above, it was found that all chapters applied authentic assessment. In speaking skill, there were 12 tasks. The division of task in each chapter remains the same, on average, each chapter had 1 to 2 tasks. Chapter that had 2 tasks can be found in chapter 1 , chapter 2 , chapter 6 , and chapter 8 . The rest 
chapters such as chapter 3 , chapter 4 , chapter 5 , and chapter 7 only had 1 task.

Authentic assessment characteristics in speaking activities were not distributed well. There were only 6 out of 9 criteria used in speaking skill. "Realistic activity or context" and "performance-based" were the most authentic assessment criteria proposed in this textbook with the total use for each characteristic was 12 times. The least authentic assessment criteria in speaking skill was "defense is required" with the total of 4 uses. Even though all tasks in speaking skill were authentic, but the characteristic of "formative assessment", "multiple indicators or portfolio", and "criteria are known by students" were not found in these speaking activities.

Table 3. Authentic Assessment in Reading Skill

\begin{tabular}{|c|c|c|c|}
\hline Chapter & Reading Tasks & Page & Authentic Assessment \\
\hline \multirow{3}{*}{$\begin{array}{l}\text { I. Offers \& } \\
\text { Suggestions }\end{array}$} & $\begin{array}{l}\text { Pre-Activity: } \\
\text { Students are asked to choose a classmate as partner and then } \\
\text { read the conversations } 1 \text { and } 2 \text { and then answers the questions } \\
\text { related to the conversation on the sheets provided }\end{array}$ & $2-3$ & $\begin{array}{l}\text { Context of the Assessment } \\
\text { - Realistic activity or context } \\
\text { - Performance based } \\
\text { Role of Student } \\
\text { - Collaborative }\end{array}$ \\
\hline & 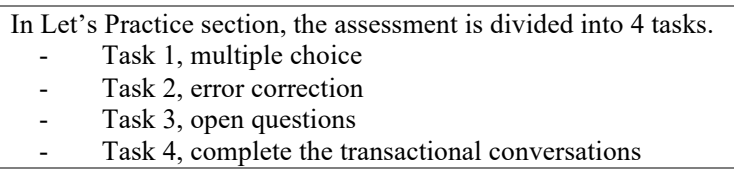 & $8-13$ & $\begin{array}{l}\text { Scoring Procedures } \\
\text { - Multiple indicator or } \\
\text { portfolio }\end{array}$ \\
\hline & $\begin{array}{l}\text { Let's Practice: } \\
\text { - In task 1, students are asked to answer the multiple } \\
\text { question, which the answers are already stated in the } \\
\text { option }\end{array}$ & $8-9$ & $\begin{array}{l}\text { Non-Authentic: } \\
\text { - Multiple choice }\end{array}$ \\
\hline \multirow[t]{2}{*}{$\begin{array}{l}\text { II. Opinions } \\
\& \text { Thoughts }\end{array}$} & $\begin{array}{l}\text { Pre-Activity: } \\
\text { Students in a partner are asked to read and role-play the } \\
\text { conversation and then discuss some questions with their partner } \\
\text { about the conversation they have read }\end{array}$ & 19 & $\begin{array}{l}\text { Context of the Assessment } \\
\text { - Realistic activity or context } \\
\text { - Performance based } \\
\text { Role of Student } \\
\text { - Collaborative } \\
\text { - Defense is required }\end{array}$ \\
\hline & $\begin{array}{l}\text { Let's Practice: } \\
\text { - In task 2, students are asked to highlight the opinions } \\
\text { whether the opinion is polite or impolite }\end{array}$ & $25-26$ & $\begin{array}{l}\text { Non-Authentic: } \\
\text { - Matching }\end{array}$ \\
\hline $\begin{array}{l}\text { III. Party } \\
\text { Time }\end{array}$ & $\begin{array}{l}\text { Pre-Activity: } \\
\text { Students are asked to read an excerpt of the play provided in the } \\
\text { textbook and then discuss some questions given in the textbook } \\
\text { and write their thoughts in the box }\end{array}$ & 33 & $\begin{array}{l}\text { Context of the Assessment } \\
\text { - Realistic activity or context } \\
\text { - Performance based } \\
\text { Role of Student } \\
\text { - Collaborative } \\
\text { - Defense is required }\end{array}$ \\
\hline $\begin{array}{l}\text { IV. National } \\
\text { Disaster-An } \\
\text { Exposition }\end{array}$ & $\begin{array}{l}\text { Pre-Activity: } \\
\text { Students are asked to read the text given and then discuss some } \\
\text { of questions in the textbook. }\end{array}$ & 46 & $\begin{array}{l}\text { Context of the Assessment } \\
\text { - Performance based } \\
\text { Role of Student } \\
\text { - Defense is required }\end{array}$ \\
\hline \multirow{3}{*}{$\begin{array}{l}\text { V. Letter } \\
\text { Writing }\end{array}$} & $\begin{array}{l}\text { Pre-Activity: } \\
\text { Students are asked to read the letter and then discuss the answer } \\
\text { of questions related to letter with their partner }\end{array}$ & 62 & $\begin{array}{l}\text { Context of the Assessment } \\
\text { - Realistic activity or context } \\
\text { - Performance based } \\
\text { Role of Student } \\
\text { - Collaborative } \\
\text { - Defense is required }\end{array}$ \\
\hline & $\begin{array}{l}\text { In Let's Practice section, the assessment is divided into } 2 \text { tasks. } \\
-\quad \text { Task 1, matching } \\
\text { - } \quad \text { Task 2, highlight mistake and rewrite letter }\end{array}$ & $68-69$ & $\begin{array}{l}\text { Scoring Procedures } \\
\text { - Multiple indicator or } \\
\text { portfolio }\end{array}$ \\
\hline & $\begin{array}{l}\text { Let's Practice: } \\
\text { - In task } 1 \text {, students are asked to match the expression } \\
\text { with the purpose of letter which the answers are already } \\
\text { stated in table }\end{array}$ & 68 & $\begin{array}{l}\text { Non-Authentic: } \\
\text { - Matching }\end{array}$ \\
\hline $\begin{array}{l}\text { VI. Cause \& } \\
\text { Effect }\end{array}$ & $\begin{array}{l}\text { Pre-Activity: } \\
\text { Students with a partner are asked to read the short conversation } \\
\text { and then discuss about smoking and its effects }\end{array}$ & 75 & $\begin{array}{l}\text { Context of the Assessment } \\
\text { - Realistic activity or context } \\
\text { - Performance based } \\
\text { Role of Student } \\
\text { - Collaborative }\end{array}$ \\
\hline VII. & Pre-Activity: & $87-95$ & Context of the Assessment \\
\hline
\end{tabular}


Journal of English Teaching Adi Buana, Vol. 06 No. 02, October 2021

\begin{tabular}{|c|c|c|c|}
\hline $\begin{array}{l}\text { Meaning } \\
\text { Through } \\
\text { Music }\end{array}$ & $\begin{array}{l}\text { Students in pairs are asked to study the lyrics songs and poems. } \\
\text { After that discuss the questions related to those songs and } \\
\text { poems. }\end{array}$ & & $\begin{array}{l}\text { - Realistic activity or context } \\
\text { - Cognitively complex } \\
\text { Role of Student } \\
\text { - Collaborative } \\
\text { - Defense is required }\end{array}$ \\
\hline $\begin{array}{l}\text { VIII. } \\
\text { Explain } \\
\text { This! }\end{array}$ & $\begin{array}{l}\text { Pre-Activity: } \\
\text { Students are asked to read the text given entitled "Earthquakes" } \\
\text { and then discuss some questions related to the text. }\end{array}$ & 100 & $\begin{array}{l}\text { Context of the Assessment } \\
\text { - Realistic activity or context } \\
\text { - Performance based }\end{array}$ \\
\hline \multirow{3}{*}{$\begin{array}{l}\text { Enrichment } \\
1\end{array}$} & $\begin{array}{l}\text { Pre-Reading Activities: } \\
\text { Students are asked to write down their wishes in space given } \\
\text { and share it with their teacher and classmates }\end{array}$ & 116 & $\begin{array}{l}\text { Context of the Assessment } \\
\text { - Realistic activity or context } \\
\text { - Performance based }\end{array}$ \\
\hline & $\begin{array}{l}\text { Reading Activity: } \\
\text { Students are asked to read the text given entitled "The } \\
\text { Enchanted Fish" }\end{array}$ & $\begin{array}{c}117- \\
119\end{array}$ & $\begin{array}{l}\text { Context of the Assessment } \\
\text { - Performance based }\end{array}$ \\
\hline & $\begin{array}{l}\text { Post-Reading Activity: } \\
\text { Students are asked to note down their opinions and reactions to } \\
\text { the questions provided in the textbook }\end{array}$ & 120 & $\begin{array}{l}\text { Role of Student } \\
\text { - Collaborative }\end{array}$ \\
\hline \multirow{3}{*}{$\begin{array}{l}\text { Enrichment } \\
2\end{array}$} & $\begin{array}{l}\text { Pre-Reading Activities: } \\
\text { Students are asked to write their feelings/opinions on the issue } \\
\text { of bullying }\end{array}$ & 123 & $\begin{array}{l}\text { Context of the Assessment } \\
\text { - Realistic activity or context }\end{array}$ \\
\hline & $\begin{array}{l}\text { Reading Activity: } \\
\text { Students are asked to read the text given entitled "Bullying: A } \\
\text { cancer that must be eradicated" }\end{array}$ & $\begin{array}{l}124- \\
126\end{array}$ & $\begin{array}{l}\text { Context of the Assessment } \\
\text { - Performance based }\end{array}$ \\
\hline & $\begin{array}{l}\text { Post-Reading Activity: } \\
\text { Students are asked to note down their opinions and reactions to } \\
\text { the questions provided in the textbook }\end{array}$ & 126 & $\begin{array}{l}\text { Context of the Assessment } \\
\text { - Realistic activity or context } \\
\text { Role of Student } \\
\text { - Collaborative } \\
\text { - Defense is required }\end{array}$ \\
\hline \multirow{3}{*}{$\begin{array}{l}\text { Enrichment } \\
3\end{array}$} & $\begin{array}{l}\text { Pre-Reading Activities: } \\
\text { Students are asked to write their hopes and aspirations in the } \\
\text { space provided }\end{array}$ & 129 & $\begin{array}{l}\text { Context of the Assessment } \\
\text { - Realistic activity or context } \\
\text { - Performance based }\end{array}$ \\
\hline & $\begin{array}{l}\text { Reading Activity: } \\
\text { Students are asked to read the text given entitled "Presidents } \\
\text { Sukarno of Indonesia" }\end{array}$ & $\begin{array}{c}130- \\
131\end{array}$ & $\begin{array}{l}\text { Context of the Assessment } \\
\text { - Performance based }\end{array}$ \\
\hline & $\begin{array}{l}\text { Post-Reading Activity: } \\
\text { Students are asked to note down their opinions and reactions to } \\
\text { the questions provided in the textbook. }\end{array}$ & 132 & $\begin{array}{l}\text { Context of the Assessment } \\
\text { - Realistic activity or context } \\
\text { Role of Student } \\
\text { - Collaborative } \\
\text { - Defense is required }\end{array}$ \\
\hline \multirow{3}{*}{$\begin{array}{l}\text { Enrichment } \\
4\end{array}$} & $\begin{array}{l}\text { Pre-Reading Activities: } \\
\text { Students are asked to write down their story about have they } \\
\text { ever borrowed something and lost it and how they try to find it }\end{array}$ & 135 & $\begin{array}{l}\text { Context of the Assessment } \\
\text { - Realistic activity or context } \\
\text { - Performance based }\end{array}$ \\
\hline & $\begin{array}{l}\text { Reading Activity: } \\
\text { Students are asked to read the text given entitled "Vanity and } \\
\text { Pride" }\end{array}$ & $\begin{array}{l}136- \\
141\end{array}$ & $\begin{array}{l}\text { Context of the Assessment } \\
\text { - Performance based }\end{array}$ \\
\hline & $\begin{array}{l}\text { Post-Reading Activity: } \\
\text { Students are asked to note down their opinions and reactions to } \\
\text { the questions provided in the textbook. }\end{array}$ & 142 & $\begin{array}{l}\text { Role of Student } \\
\text { - Collaborative } \\
\text { - Defense is required }\end{array}$ \\
\hline \multirow{3}{*}{$\begin{array}{l}\text { Enrichment } \\
5\end{array}$} & $\begin{array}{l}\text { Pre-Reading Activities: } \\
\text { Students are asked to write their thoughts about the situation } \\
\text { given and describe their feelings }\end{array}$ & 145 & $\begin{array}{l}\text { Context of the Assessment } \\
\text { - Realistic activity or context } \\
\text { - Performance based }\end{array}$ \\
\hline & $\begin{array}{l}\text { Reading Activity: } \\
\text { Students are asked to read the text given entitled "Letter to } \\
\text { GOD" }\end{array}$ & $\begin{array}{c}146- \\
149\end{array}$ & $\begin{array}{l}\text { Context of the Assessment } \\
\text { - Performance based }\end{array}$ \\
\hline & $\begin{array}{l}\text { Post-Reading Activity: } \\
\text { Students are asked to note down their opinions and reactions to } \\
\text { the questions provided in the textbook }\end{array}$ & 150 & $\begin{array}{l}\text { Context of the Assessment } \\
\text { - Realistic activity or context } \\
\text { Role of the Student } \\
\text { - Defense is required }\end{array}$ \\
\hline \multirow{3}{*}{$\begin{array}{l}\text { Enrichment } \\
6\end{array}$} & $\begin{array}{l}\text { Pre-Reading Activities: } \\
\text { Students are asked to write or describe their experience in the } \\
\text { space given }\end{array}$ & 153 & $\begin{array}{l}\text { Context of the Assessment } \\
\text { - Realistic activity or context }\end{array}$ \\
\hline & $\begin{array}{l}\text { Reading Activity: } \\
\text { Students are asked to read the text given entitled "The Last } \\
\text { Leaf" }\end{array}$ & $\begin{array}{c}154- \\
156\end{array}$ & $\begin{array}{l}\text { Context of the Assessment } \\
\text { - Performance based }\end{array}$ \\
\hline & $\begin{array}{l}\text { Post-Reading Activity: } \\
\text { Students are asked to note down their opinions and reactions to } \\
\text { the questions provided in the textbook }\end{array}$ & 157 & $\begin{array}{l}\text { Context of the Assessment } \\
\text { - Realistic activity or context } \\
\text { Role of the Student } \\
\text { - Defense is required }\end{array}$ \\
\hline $\begin{array}{l}\text { Enrichment } \\
7\end{array}$ & $\begin{array}{l}\text { Pre-Reading Activities: } \\
\text { Students are asked to write down what they would do for people } \\
\text { and their country so that someone will write a biography about }\end{array}$ & 160 & $\begin{array}{l}\text { Context of the Assessment } \\
\text { - Realistic activity or context }\end{array}$ \\
\hline
\end{tabular}




\begin{tabular}{|c|c|c|}
\hline $\begin{array}{l}\text { Reading Activity: } \\
\text { Students are asked to read the text given entitled "Life and } \\
\text { Times of Ki Hajar Dewantara (Raden Mas Suwardi } \\
\text { Suryaningrat)" }\end{array}$ & $\begin{array}{c}161- \\
162\end{array}$ & $\begin{array}{l}\text { Context of the Assessment } \\
\text { - Performance based }\end{array}$ \\
\hline $\begin{array}{l}\text { Post-Reading Activity: } \\
\text { Students are asked to note down their opinions and reactions to } \\
\text { the questions provided in the textbook }\end{array}$ & 163 & $\begin{array}{l}\text { Context of the Assessment } \\
\text { - Realistic activity or context } \\
\text { Role of the Student } \\
\text { - Defense is required }\end{array}$ \\
\hline
\end{tabular}

From Table 3, it was found that all chapters were applied authentic assessment. There were 32 tasks for reading activities, including activities in main chapters and enrichments. The division of tasks of chapter 3 , chapter 4 , chapter 6 , chapter 7 , and chapter 8 had the same number of tasks proportion where each chapter had 1 task. While, the other three chapters, namely chapter 1 , chapter 2 , and chapter 5 had two tasks respectively. The division of enrichment activities was divided equally, each chapter had three activities containing pre-reading activities, reading activity, and post-reading activity.

The authentic assessment characteristic spread over three or four criteria for each chapter. The most criteria were in chapter 5 and the least criteria was found in chapter 8 . Among all chapters, "realistic activity or context" was the most authentic assessment criteria used in reading activities with the total of 19 uses. Meanwhile, "multiple indicators or portfolio" was the least criteria used in reading activities by total 2 times of use. Thus, "formative assessments", "criteria known by students", and "mastery expectation" were not found in reading activities.

However, not all criteria of authentic assessment were well distributed in this book because there were 6 out of 9 criteria found in this reading tasks and there were also non-authentic assessments. In this textbook, there are 3 assessments that are non-authentic, for instance in chapter 1 page $8-9$, in chapter 2 page $25-26$, and in chapter 5 page 68 . Those assessments are not authentic because the types of tasks were multiple choice test and matching. Those assessments are disconnected from a realistic context and realistic constraints. In line with Mueller (2005), nonauthentic assessment or traditional assessment refer to the forced-choice measures of the multiple-choice, fill-in-the-blank, true-false, matching and similar tests remain so common in education.

Table 4. Authentic Assessment in Writing Skill

\begin{tabular}{|c|c|c|c|}
\hline Chapter & Writing Tasks & Page & Authentic Assessment \\
\hline \multirow{3}{*}{$\begin{array}{l}\text { I. Offers \& } \\
\text { Suggestions }\end{array}$} & $\begin{array}{l}\text { Let's Practice: } \\
\text { - In task 2, students are asked to find grammatical errors } \\
\text { in the sentence, then rewrite the correct sentence } \\
\text { - In task 3, students are asked to write response of each } \\
\text { question related to suggestion and offers } \\
\text { - In task 4, students are asked to complete the } \\
\text { transactional conversations }\end{array}$ & $9-13$ & $\begin{array}{l}\text { Context of the Assessment } \\
\text { - Cognitively complex } \\
\text { - Realistic activity or context } \\
\text { Scoring Procedures } \\
\text { - Mastery Expectation }\end{array}$ \\
\hline & $\begin{array}{l}\text { Writing Connection: } \\
\text { Students with a partner are asked to write a dialogue using } \\
\text { suggestions and offer }\end{array}$ & 15 & $\begin{array}{l}\text { Context of the Assessment } \\
\text { - Realistic activity or context } \\
\text { - Cognitively complex } \\
\text { - Performance based } \\
\text { Role of Students } \\
\text { - Collaborative } \\
\text { Scoring Procedures } \\
\text { - Mastery Expectation }\end{array}$ \\
\hline & $\begin{array}{l}\text { Let's Create/Contribute: } \\
\text { Students are asked to make pairs and then choose one of the } \\
\text { tasks given in the Let's Create/Contribute section: } \\
\text { - Creating the postcard based on the situation given } \\
\text { that related to suggestion and offer }\end{array}$ & 16 & $\begin{array}{l}\text { Context of the Assessment } \\
\text { - Realistic activity or context } \\
\text { - Cognitively complex } \\
\text { - Performance based } \\
\text { Role of Students }\end{array}$ \\
\hline
\end{tabular}


Journal of English Teaching Adi Buana, Vol. 06 No. 02, October 2021

\begin{tabular}{|c|c|c|c|}
\hline & & & $\begin{array}{l}\text { - Collaborative } \\
\text { Scoring Procedures } \\
\text { - Mastery Expectation }\end{array}$ \\
\hline & $\begin{array}{l}\text { Formative Assessment: } \\
\text { Students are asked to do reflection and self-assessment of what } \\
\text { they have done }\end{array}$ & 17 & $\begin{array}{l}\text { Role of Students } \\
\text { - Formative Assessment }\end{array}$ \\
\hline \multirow{4}{*}{$\begin{array}{l}\text { II. Opinions } \\
\& \text { Thoughts }\end{array}$} & 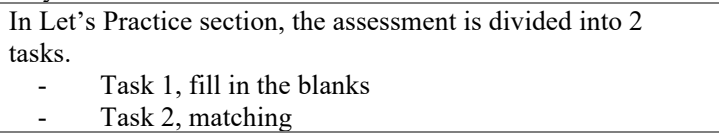 & $25-26$ & $\begin{array}{l}\text { Scoring Procedures } \\
\text { - Multiple indicator or portfolio }\end{array}$ \\
\hline & $\begin{array}{l}\text { Let's Practice: } \\
-\quad \text { In task } 1 \text {, students are asked to fill in the blanks, } \\
\text { which the answers are already stated in the box }\end{array}$ & 25 & $\begin{array}{l}\text { Non-Authentic: } \\
\text { - Fill in the blank }\end{array}$ \\
\hline & $\begin{array}{l}\text { Writing Connection: } \\
\text { Students are asked to write their opinions regarding various } \\
\text { issues and create an opinion dialog supported with reasons and } \\
\text { examples using opinion giving technique that they have learnt }\end{array}$ & 28 & $\begin{array}{l}\text { Context of the Assessment } \\
\text { - Realistic activity or context } \\
\text { - Cognitively complex } \\
\text { - Performance based } \\
\text { Role of Students } \\
\text { - Defense is required } \\
\text { Scoring Procedures } \\
\text { - Mastery Expectation }\end{array}$ \\
\hline & $\begin{array}{l}\text { Formative Assessment: } \\
\text { Students are asked to do reflection and self-assessment of what } \\
\text { they have done }\end{array}$ & 31 & $\begin{array}{l}\text { Role of Students } \\
\text { - Formative Assessment }\end{array}$ \\
\hline \multirow{4}{*}{$\begin{array}{l}\text { III. Party } \\
\text { Time }\end{array}$} & $\begin{array}{l}\text { Let's Practice: } \\
\text { Students are asked to find out what is missing in the invitation } \\
\text { card, next rewrite the invitation properly in the space given in } \\
\text { the textbook, and write the respond of the invitation }\end{array}$ & $39-40$ & $\begin{array}{l}\text { Context of the Assessment } \\
\text { - Realistic activity or context } \\
\text { - Cognitively complex } \\
\text { - Performance based } \\
\text { Scoring Procedures } \\
\text { - Mastery Expectation }\end{array}$ \\
\hline & $\begin{array}{l}\text { Writing Connection: } \\
\text { Students are asked to write a formal invitation (wedding } \\
\text { invitation) using the knowledge they have acquired. }\end{array}$ & 42 & $\begin{array}{l}\text { Context of the Assessment } \\
\text { - Realistic activity or context } \\
\text { - Cognitively complex } \\
\text { - Performance based } \\
\text { Scoring Procedures } \\
\text { - Mastery Expectation }\end{array}$ \\
\hline & $\begin{array}{l}\text { Let's Create/Contribute: } \\
\text { Students are asked to create a formal invitation. There are } 3 \\
\text { projects in this section and the students can choose whichever } \\
\text { they like and work on it with their friends }\end{array}$ & 43 & $\begin{array}{l}\text { Context of the Assessment } \\
\text { - Realistic activity or context } \\
\text { - Cognitively complex } \\
\text { - Performance based } \\
\text { Role of Students } \\
\text { - Collaborative } \\
\text { Scoring Procedures } \\
\text { - Mastery Expectation }\end{array}$ \\
\hline & $\begin{array}{l}\text { Formative Assessment: } \\
\text { Students are asked to do reflection and self-assessment of what } \\
\text { they have done. }\end{array}$ & 44 & $\begin{array}{l}\text { Role of Students } \\
\text {-Formative Assessment }\end{array}$ \\
\hline \multirow{4}{*}{$\begin{array}{l}\text { IV. National } \\
\text { Disaster-An } \\
\text { Exposition }\end{array}$} & $\begin{array}{l}\text { Let's Practice: } \\
\text { Students are asked to complete the article by giving their } \\
\text { arguments and conclusion }\end{array}$ & 52 & $\begin{array}{l}\text { Context of the Assessment } \\
\text { - Realistic activity or context } \\
\text { - Cognitively complex } \\
\text { - Performance based } \\
\text { Scoring Procedures } \\
\text { - Mastery Expectation }\end{array}$ \\
\hline & $\begin{array}{l}\text { Writing Connection: } \\
\text { Students are asked to choose the most popular issue in the } \\
\text { media and write an analytical exposition about it. }\end{array}$ & $56-58$ & $\begin{array}{l}\text { Context of the Assessment } \\
\text { - Realistic activity or context } \\
\text { - Cognitively complex } \\
\text { - Performance based } \\
\text { Scoring Procedures } \\
\text { - Mastery Expectation }\end{array}$ \\
\hline & $\begin{array}{l}\text { Let's Create/Contribute: } \\
\text { Students are asked to choose one of the activities provided in } \\
\text { "Let's Create/ Contribute" section: } \\
\text { - } \quad \text { Write an exposition text on conversation of animals } \\
\text { and use the exposition text that have been made by } \\
\text { students as speech for the opening of the event. } \\
\text { Make posters to depict the plight of innocent } \\
\text { creatures that are killed or captured by poachers } \\
\text { - Create a pamphlet or movie to educate people in } \\
\text { school on "Dangers of drug abuse and cigarette } \\
\text { smoking" }\end{array}$ & 59 & $\begin{array}{l}\text { Context of the Assessment } \\
\text { - Realistic activity or context } \\
\text { - Cognitively complex } \\
\text { - Performance based } \\
\text { Scoring Procedures } \\
\text { - Mastery Expectation }\end{array}$ \\
\hline & $\begin{array}{l}\text { Formative Assessment: } \\
\text { Students are asked to do reflection and self-assessment of what }\end{array}$ & 60 & $\begin{array}{l}\text { Role of Students } \\
\text { - Formative Assessment }\end{array}$ \\
\hline
\end{tabular}




\begin{tabular}{|c|c|c|c|}
\hline & they have done & & \\
\hline \multirow{4}{*}{$\begin{array}{l}\text { V. Letter } \\
\text { Writing }\end{array}$} & $\begin{array}{l}\text { Let's Practice: } \\
\text { - In task 2, students are asked to analyzed and } \\
\text { highlight the mistakes in the letter then rewrite the } \\
\text { proper letter }\end{array}$ & $68-69$ & $\begin{array}{l}\text { Context of the Assessment } \\
\text { - Realistic activity or context } \\
\text { - Cognitively complex } \\
\text { Scoring Procedures } \\
\text { - Mastery Expectation }\end{array}$ \\
\hline & $\begin{array}{l}\text { Writing Connection: } \\
\text { Students are asked to write a letter and use the proper letter- } \\
\text { writing they have learnt. }\end{array}$ & 71 & $\begin{array}{l}\text { Context of the Assessment } \\
\text { - Realistic activity or context } \\
\text { - Cognitively complex } \\
\text { - Performance based } \\
\text { Scoring Procedures } \\
\text { - Mastery Expectation }\end{array}$ \\
\hline & $\begin{array}{l}\text { Let's Create/Contribute: } \\
\text { Students are asked choose whether they want to write a letter } \\
\text { or in pairs to create a postage stamp and letter-writing pad. }\end{array}$ & 72 & $\begin{array}{l}\text { Context of the Assessment } \\
\text { - Realistic activity or context } \\
\text { - Cognitively complex } \\
\text { - Performance based } \\
\text { Role of Students } \\
\text { - Collaborative } \\
\text { Scoring Procedures } \\
\text { - Mastery Expectation }\end{array}$ \\
\hline & $\begin{array}{l}\text { Formative Assessment: } \\
\text { Students are asked to do reflection and self-assessment of what } \\
\text { they have done }\end{array}$ & 73 & $\begin{array}{l}\text { Role of the Student } \\
\text { - Formative Assessment }\end{array}$ \\
\hline \multirow{4}{*}{$\begin{array}{l}\text { VI. Cause \& } \\
\text { Effect }\end{array}$} & 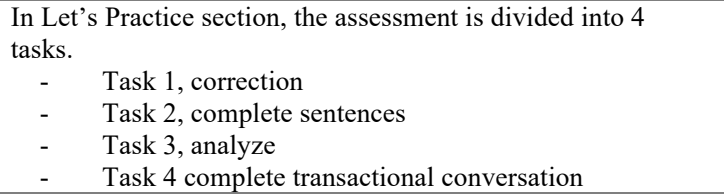 & $79-81$ & $\begin{array}{l}\text { Scoring Procedures } \\
\text { - Multiple indicator or portfolio }\end{array}$ \\
\hline & $\begin{array}{l}\text { Let's Practice: } \\
\text { - In task } 1 \text {, students are asked to analyze the cause } \\
\text { and effect in the sentences and then underline the } \\
\text { signal word or phrases } \\
\text { - } \quad \text { In task } 2 \text {, students are asked to read the cause and } \\
\text { then write the effect and complete sentences by } \\
\text { using signal words } \\
\text { - } \quad \text { In task } 3 \text {, students are asked to find the cause-and- } \\
\text { - } \quad \text { Infect of the sentences } \\
\text { and-effect transactional conversation }\end{array}$ & $79-81$ & $\begin{array}{l}\text { Context of the Assessment } \\
\text { - Realistic activity or context } \\
\text { - Cognitively complex } \\
\text { Scoring Procedures } \\
\text { - Mastery Expectation }\end{array}$ \\
\hline & $\begin{array}{l}\text { Writing Connection: } \\
\text { Students are asked to choose one of the topics given and create } \\
\text { a dialogue about it. }\end{array}$ & 83 & $\begin{array}{l}\text { Context of the Assessment } \\
\text { - Realistic activity or context } \\
\text { - Cognitively complex } \\
\text { - Performance based } \\
\text { Scoring Procedures } \\
\text { - Mastery Expectation }\end{array}$ \\
\hline & $\begin{array}{l}\text { Formative Assessment: } \\
\text { Students are asked to do reflection and self-assessment of what } \\
\text { they have done }\end{array}$ & 85 & $\begin{array}{l}\text { Role of the Student } \\
\text { - Formative Assessment }\end{array}$ \\
\hline $\begin{array}{l}\text { VII. } \\
\text { Meaning } \\
\text { Through } \\
\text { Music }\end{array}$ & $\begin{array}{l}\text { Formative Assessment: } \\
\text { Students are asked to do reflection and self-assessment of what } \\
\text { they have done }\end{array}$ & 98 & $\begin{array}{l}\text { Role of the Student } \\
\text { - Formative Assessment }\end{array}$ \\
\hline \multirow{3}{*}{$\begin{array}{l}\text { VIII Explain } \\
\text { This! }\end{array}$} & $\begin{array}{l}\text { Let's Practice: } \\
\text { Students are asked to complete the explanation text using the } \\
\text { opening statement of a phenomenon that has been given }\end{array}$ & 107 & $\begin{array}{l}\text { Context of the Assessment } \\
\text { - Realistic activity or context } \\
\text { - Performance based } \\
\text { Scoring Procedures } \\
\text { - Mastery Expectation }\end{array}$ \\
\hline & $\begin{array}{l}\text { Writing Connection: } \\
\text { Students are asked to choose one topic provided in the active } \\
\text { conversation section or any topic the have chosen and then } \\
\text { write the explanation text based on the topics they have } \\
\text { chosen. }\end{array}$ & $\begin{array}{c}109- \\
111\end{array}$ & $\begin{array}{l}\text { Context of the Assessment } \\
\text { - Realistic activity or context } \\
\text { - Performance based } \\
\text { Scoring Procedures } \\
\text { - Mastery Expectation }\end{array}$ \\
\hline & $\begin{array}{l}\text { Formative Assessment: } \\
\text { Students are asked to do reflection and self-assessment of what } \\
\text { they have done }\end{array}$ & 113 & $\begin{array}{l}\text { Role of the Student } \\
\text { - Formative Assessment }\end{array}$ \\
\hline $\begin{array}{l}\text { Enrichment } \\
1\end{array}$ & $\begin{array}{l}\text { Personal Journal Writing: } \\
\text { Students are asked to write down and share their thoughts of } \\
\text { what things they are grateful for }\end{array}$ & 121 & $\begin{array}{l}\text { Context of the Assessment } \\
\text { - Realistic activity or context } \\
\text { - Performance based }\end{array}$ \\
\hline $\begin{array}{l}\text { Enrichment } \\
2\end{array}$ & $\begin{array}{l}\text { Personal Journal Writing: } \\
\text { Students are asked to write down their feelings and what }\end{array}$ & 127 & $\begin{array}{l}\text { Context of the Assessment } \\
\text { - Realistic activity or context }\end{array}$ \\
\hline
\end{tabular}


Journal of English Teaching Adi Buana, Vol. 06 No. 02, October 2021

\begin{tabular}{|c|c|c|c|}
\hline & $\begin{array}{l}\text { would they do if they are a person who gets bullied every day } \\
\text { at school }\end{array}$ & & $\begin{array}{l}\text { - Cognitively complex } \\
\text { - Performance based }\end{array}$ \\
\hline $\begin{array}{l}\text { Enrichment } \\
3\end{array}$ & $\begin{array}{l}\text { Personal Journal Writing: } \\
\text { Students are asked to write down why hopes and dreams are } \\
\text { necessary for success in life }\end{array}$ & 133 & $\begin{array}{l}\text { Context of the Assessment } \\
\text { - Realistic activity or context } \\
\text { - Performance based } \\
\text { Role of Students } \\
\text { - Defense is required }\end{array}$ \\
\hline $\begin{array}{l}\text { Enrichment } \\
4\end{array}$ & $\begin{array}{l}\text { Personal Journal Writing: } \\
\text { Students are asked to write down what would they do if they } \\
\text { were Madam Loisel and what do they think about being honest } \\
\text { is very important in life }\end{array}$ & 143 & $\begin{array}{l}\text { Context of the Assessment } \\
\text { - Realistic activity or context } \\
\text { - Cognitively complex } \\
\text { - Performance based }\end{array}$ \\
\hline $\begin{array}{l}\text { Enrichment } \\
5\end{array}$ & $\begin{array}{l}\text { Personal Journal Writing: } \\
\text { Students are asked to choose on of topics to reflect and then } \\
\text { write their diary on the topic they have chosen }\end{array}$ & 151 & $\begin{array}{l}\text { Context of the Assessment } \\
\text { - Realistic activity or context } \\
\text { - Cognitively complex } \\
\text { - Performance based }\end{array}$ \\
\hline $\begin{array}{l}\text { Enrichment } \\
6\end{array}$ & $\begin{array}{l}\text { Personal Journal Writing: } \\
\text { Students are asked to write down their feelings and what } \\
\text { would they do if they are a person who gets bullied every day } \\
\text { at school }\end{array}$ & 158 & $\begin{array}{l}\text { Context of the Assessment } \\
\text { - Realistic activity or context } \\
\text { - Cognitively complex } \\
\text { - Performance based }\end{array}$ \\
\hline $\begin{array}{l}\text { Enrichment } \\
7\end{array}$ & $\begin{array}{l}\text { Personal Journal Writing: } \\
\text { Students are asked to write down their feelings and what } \\
\text { would they do if they are a person who gets bullied every day } \\
\text { at school }\end{array}$ & 164 & $\begin{array}{l}\text { Context of the Assessment } \\
\text { - Realistic activity or context } \\
\text { - Cognitively complex } \\
\text { - Performance based }\end{array}$ \\
\hline
\end{tabular}

Based on Table 4, all chapters applied authentic assessment. Writing activities had the most tasks, with the total of tasks was 33 tasks. The distribution of tasks remained the same in each chapter. Each chapter had three to four tasks for writing activities. Only 1 chapter had one activity. The most tasks were found in chapter 1 , chapter 3 , chapter 4 , and chapter 5 with each chapter having 4 tasks in maximum. The least tasks were found in chapter 7 with only 1 task and 1 characteristic of authentic assessment. Authentic assessment characteristic in writing activities was not distributed well. "Realistic activity or context" was the most authentic assessment criteria used in this textbook, with the total of 24 uses. The least authentic assessment criteria were "defense is required" and "multiple indicators or portfolio" with the total of 2 uses. Even though all tasks were authentic, the characteristic of "criteria are known by students" was not found in writing activities.

Table 5. Frequency of Authentic Assessment

\begin{tabular}{|c|c|c|c|c|}
\hline Authentic Assessment & $\begin{array}{c}\text { Main } \\
\text { Material }\end{array}$ & Enrichment & Total & Percentage \\
\hline \multicolumn{5}{|l|}{ Context of Assessment } \\
\hline $\begin{array}{l}\text { 1. Realistic Activity or } \\
\text { Context }\end{array}$ & 37 & 19 & 56 & $25 \%$ \\
\hline 2. Cognitively Complex & 27 & 5 & 32 & $14.3 \%$ \\
\hline 3. Performance Based & 33 & 18 & 51 & $22.8 \%$ \\
\hline \multicolumn{5}{|l|}{ Role of Students } \\
\hline 1. Formative Assessment & 8 & - & 8 & $3.6 \%$ \\
\hline 2. Collaborative & 20 & 4 & 24 & $10.7 \%$ \\
\hline 3. Defense is Required & 10 & 7 & 17 & $7.6 \%$ \\
\hline \multicolumn{5}{|l|}{ Scoring Procedures } \\
\hline $\begin{array}{l}\text { 1. Multiple Indicators or } \\
\text { portfolio }\end{array}$ & 4 & - & 4 & $1.8 \%$ \\
\hline $\begin{array}{l}\text { 2. Criteria Known by } \\
\text { Students }\end{array}$ & - & - & - & $0 \%$ \\
\hline 3. Mastery Expectation & 28 & - & 28 & $12.5 \%$ \\
\hline Non-Authentic & 4 & - & 4 & $1.8 \%$ \\
\hline
\end{tabular}

From Table 5, it can be seen that "realistic activity or context" was the most authentic assessment criteria used in this textbook. While, "multiple indicators or portfolio" was the least authentic assessment criteria, and "criteria known by 
students" was nowhere found this English textbook.

\section{Discussion}

The findings presented above signposted that authentic assessments were used in the English four skills: reading, writing, speaking, and listening. The textbooks that have been analyzed have fulfilled most of the characteristic of the authentic assessment. "Realistic activity or context" was used 56 times and mostly found in writing tasks. Frey (2013) argued, it is reasonable the assessments should correspond to real-world tasks and expectations. The tasks should give a clearer image of the students' most essential abilities. Students will be prepared for success in whatever comes next in their real-world careers with those skills and knowledge sets.

Most the context or activities in the textbook used realistic situation. The context can be used in student's daily life. "Performance based" was used 51 times and mostly found in writing tasks. Performance based also known as alternative to authentic assessment. It required the students to perform a task rather than choose from ready-made list choices. "Cognitively complex" was used 32 times and mostly found in writing tasks. As claimed by Frey (2013), authentic assessment focuses on HOTS (higher-order thinking skills), problem solving, inquiry, and analysis to improve teaching and curriculum coverage. The tasks required thinking at high levels of Bloom's Taxonomy. Authentic assessment sharpens students' higherorder thinking when the student analyzes, synthesize, identify and solve problems, as well as incorporating the analysis of causation (Johnson \& Johnson, 2002).

"Defense is required" was used 17 times and mostly found in reading tasks. Some tasks in textbook required the students to depend or give supporting answers. "Collaborative" was used 24 times and mostly found in reading and speaking tasks. The tasks need students to work in pairs or groups. The real world of tasks require collaboration. As students work and learn in groups, collaborative projects allow for the assessment of collaboration skills (Frey, 2013). "Formative assessment" was used 8 times and only found in writing tasks. "Multiple indicators or portfolio" was used 4 times and can be found in reading and writing tasks. "Criteria known by students" was not used in the textbook. "Mastery expectation" was used 28 times and mostly found in writing tasks. Non-authentic assessment also found 4 times and mostly in reading tasks.

The instruction of all activities in each chapter was clear. It can make the students to understand the material and tasks easier. More than that, it also provided seven enrichments in the end of textbook. Teachers can utilize enrichment books to supplement the textbook and urge students to read them to expand their knowledge and understanding.

However, a small number of tasks still used traditional assessments in the form of multiple choice, matching, gap filling. This is not in accordance with the demands of authentic assessment, as stated by Frey (2013) that the students do not answer multiple choice question in real-world, so any multiple-choice test is bound to be more artificial. Nitko \& Brookhart (2011) also say that "paper pencil task permit student not only to record their answer but also to give explanation, articulate their reasoning, and express their own approaches toward solving a problem".

The textbook did not use "criteria known by students". Scoring rules can be found in the teacher's book, but cannot be found in the student's book. This can 
also be ascertained because there was no order that the teacher have to explain the scoring rules to students in the description of learning activities in the teacher's book. So, there is no way for students to know how the teachers assess their tasks. If the scoring criteria are made collaboratively, then this indicates that both teachers and students can share a fairly precise understanding of how the criteria should be applied (Frey, 2013).

The scoring rules should be known by students because it has several advantages such as: (a) making the goals of learning clearer, (b) guiding the instructional design, (c) improving the accuracy and fairness of the assessment process, and (d) providing students with a tool for self-assessment and peer feedback, (Wolf \& Stevens, 2007). Scoring rules were commonly used to communicate quality expectations around assignments and to describe consistent scoring criteria. Scoring rules should be known by the students and teachers to evaluate criteria, which can be complex and subjective. But, in this textbook there is no found explanation or instruction about scoring rules and the criteria. Menéndez-Varela \& Gregori-Giralt (2016) argue that it is need to consider that scoring rules as a first level teaching resource and not only as an assessment tool. Scoring rules can also provide a basis for self-assessment, peer-assessment, and reflection. Reflection. It aims for a fair and accurate assessment, stimulates understanding, and demonstrates how to continue learning.

The textbook also is not completed by other supporting materials, such as cassettes and CD. There is no audio or CD for listening section and there is no vocabulary list for supporting the learning activity. The objective of the educational program can be accomplished by providing students with as many English exposures as possible to improve their listening skill. In fact, this skill was the smallest proportion in the textbook. Crystal (2015) says that the first skill that students should develop when learning a language is listening. It means that the four language skills are interconnected, and students should focus on listening first. Without listening, no communication can be accomplished, because the students can continue to talk, read, and write after listening. It would be preferable if the listening skill has more portion in this textbook.

\section{CONCLUSION}

Based on the findings and discussions of this research, it can be concluded that English textbook for eleventh grade of senior high school "Stop Bullying Now" published by the Ministry of Education and Culture of Indonesia has applied authentic assessment. The textbook used eight out of nine characteristics of authentic assessment. First category is context of the assessment; (1) Realistic Activity or Context (25\%), the activities and context of this textbook used realistic situations such as applying offers and suggestions in real life, express opinions and thoughts, invitation, letter, and music. (2) Cognitively Complex (14,3\%), many tasks provided in the textbook required higher order thinking skills such problem solving, analysis, design posters and create letters. (3) Performance Based (22,8\%), skill or ability of students is assessed through performance or creation of product which in this textbook the students were asked to perform a dialogue, re-enact the conversation, or make a creation of product such posters and journal.

Second category is role of students; (4) Formative Assessment (3,6\%), at the end of each chapter of textbook presented formative assessment for students to 
control their own learning. (5) Collaborative (10,7\%), in this textbook, some tasks required students to work in pairs or groups. (6) Defense is Required (7,6\%), several tasks in the textbooks asked students to give supporting answers to defend student's answer.

Third category is scoring rules; (7) Multiple Indicators or Portfolio $(1,8 \%)$, the score on the assessment of some section in textbook is a composite of multiple components of students' work. (8) Mastery Expectation (12,5\%), the tasks in textbook are designed to provide feedback on whether the student has mastered a skill or ability of what has been learned.

There were also non-authentic $(1,8 \%)$ in the textbook. Some tasks provided in the form of multiple-choice, fill in the blank, and matching which those assessments are not authentic and disconnect from real-world. However, the textbook did not provide the characteristic of "criteria are known by students". The students did not know how the teachers assess their work. The most dominant characteristic of authentic assessment used in English textbook was "realistic activity or context". The category used most authentic assessment in textbook was the context of assessment.

Authentic assessments were applied in four skills: listening, speaking, reading, and writing. The most skill used authentic assessments in this textbook was writing skill. However, among those skills, listening was the skill which rarely applied authentic assessment. Among eight chapters only one chapter required listening skill of students. The textbook did not provide $\mathrm{CD}$ or cassettes for listening section. It makes the textbook had unbalance proportion of skills.

\section{REFERENCES}

Alemi, M., \& Ebadi, S. (2010). The Effects of Pre-reading Activities on ESP Reading Comprehension. Journal of Language Teaching and Research. https://doi.org/10.4304/j1tr.1.5.569-577

Anshar, M. R., Emilia, E., \& Damayanti, I. L. (2014). the Evaluation of English Electronic Books for Junior High School in Indonesia. Ilmu Pendidikan Dan Pengajaran, 1.

Aslan, C. (2010). An analysis of Turkish and French literature textbooks' outer structure and visual elements. Procedia - Social and Behavioral Sciences. https://doi.org/10.1016/j.sbspro.2010.03.120

Crystal, D. (2015). Ensiklopedi Bahasa The Cambridge Encyclopedia of Language. Nuansa Cendikia.

Cunningsworth, A. (1995). Choosing your coursebook. Macmillan Heinemann.

Fitriyani, M. (2013). a Textbook Analysis of "When English Rings the Bell" an Textbook for the Seventh Grade of Junior High. 27.

Frey, B. B. (2013). Authentic Assessment. In Modern Classroom Assessment. SAGE Publications, Inc. https://doi.org/10.4135/9781506374536.n8

Frey, B. B., Schmitt, V. L., \& Allen, J. P. (2012). Defining authentic classroom assessment. Practical Assessment, Research and Evaluation.

Handayani, S. (2016). The Evaluation of English Textbook for Grade VII of Junior High School in Indonesia. Iselt. 
Johnson, D. W., \& Johnson, R. T. (2002). Meaningful Assessment A Manageable and Cooperatve Process (1st ed.). Ally \& Dacon A Pearson Education Company.

Kasmaienezhadfard, S., Pourrajab, M., \& Rabbani, M. (2015). Effects of Pictures in Textbooks on Students' Creativity. Multi Disciplinary Edu Global Quest.

Menéndez-Varela, J. L., \& Gregori-Giralt, E. (2016). The contribution of rubrics to the validity of performance assessment: a study of the conservationrestoration and design undergraduate degrees. Assessment and Evaluation in Higher Education. https://doi.org/10.1080/02602938.2014.998169

Miles, M. B., Huberman, M., \& Saldana, J. (2014). Qualitative Data Analysis (H. Salmon (ed.); 3rd ed.). SAGE Publications, Inc. http://ibrary1.nida.ac.th/termpaper6/sd/2554/19755.pdf

Mueller, J. (2005). The Authentic Assessment Toolbox: Enhancing Student Learning through Online Faculty Development. Merlot Journal of Online Learning \& Teaching.

Nitko, A. J., \& Brookhart, S. M. (2011). Educational Assessment of Students (6th ed.). Pearson.

Sari, M. E., Zaim, M., \& Refnaldi, R. (2019). Evaluation of Authentic Assessment for Writing Skill at Junior High Schools in West Sumatera. Lingua Didaktika: Jurnal Bahasa Dan Pembelajaran Bahasa. https://doi.org/10.24036/ld.v12i2.102384

Sitepu, B. (2012). Penulisan Buku Teks Pelajaran. Remaja Rosdakarya.

Swanepoel, S. (2010). The assessment of the quality of science education textbooks : Conceptual framework and instruments for analysis. Assessment, April.

Tosun, S. (2013). A Comparative Study on Evaluation of Turkish and English Foreign Language Textbooks. Procedia - Social and Behavioral Sciences. https://doi.org/10.1016/j.sbspro.2013.01.199

Trigueros, R. (2017). Qualitative and Quantitative Research Instruments Research Tools. Universidad de El Salvador, Facultad Multidisciplinaria de Occidente, English Language Department.

Wolf, K., \& Stevens, E. (2007). The role of rubrics in advancing and assessing student learning. The Journal of Effective Teaching, 7(1), 3-14.

Zaim, M. (2013). Asesmen Otentik: Implementasi dan Permasalahannya Dalam Pembelajaran Bahasa Inggris di Sekolah Menengah. International Seminar on Languange and Arts.

Zed, M. (2014). Metode Penelitian Kepustakaan. Yayasan Pustaka Obor Indonesia. 